\title{
Wioleta Bryniewicz
}

(Uniwersytet Szczeciński,Instytut Socjologii)

\section{Jakość życia kobiet w średnim wieku - podejście holistyczne}

Za prekursora badań nad jakością życia uważa się A. Campbella, który w 1971 r. dokonał pomiaru zadowolenia z życia mieszkańców Stanów Zjednoczonych. Już wówczas uznał, że na jakość życia człowieka składają się takie aspekty jak: relacje społeczne (małżeństwo, życie rodzinne, sąsiedzi, znajomi, środowisko zawodowe), zdrowie, zajęcia domowe, praca zawodowa oraz poziom wykształcenia. Z kolei polska badaczka jakości życia K. de Walden-Gałuszko uznała w swojej definicji, iż ,jakość życia to ocena własnej sytuacji życiowej, dokonana w określonym czasie i uwzględniająca przyjęta hierarchię wartości lub też różnica pomiędzy realna sytuacją człowieka a sytuacja przez niego wymarzona” (Papuć 2011/12:143). Z socjologicznego punktu widzenia jakość życia dotyczy sposobu i stopnia zaspokajania różnych potrzeb, w tym także sposobu postrzegania osiagniętego standardu życia (Tobiasz-Adamczyk 1996).

W literaturze przedmiotu istnieje wiele definicji jakości życia, co z jednej strony uwidacznia wieloaspektowość tego pojęcia, z drugiej strony jest wyrazem braku konsensusu. W konsekwencji nie dysponuje się ostatecznym interdyscyplinarnym narzędziem badawczym, które służyłoby badaniom jakości życia. Trudno nie zgodzić się ze stwierdzeniem: „wszyscy wiemy czym jest jakość życia, ale nikt nie potrafi jej zdefiniować. A bez tej definicji pomiar jakości życia nie jest możliwy" (Papuć 2011:143).

Wśród badaczy dość często pojawia się przekonanie, że choć jakość życia i stan zdrowia są niezależnymi pojęciami, a głównymi wyznacznikami jakości życia są czynniki psychologiczne, uwzględnianie aspektu choroby może wpływać na ocenę jakości życia i włączanie go do badań wydaje się zasadne.

Szczególnym etapem w życiu kobiety jest wiek średni, zwłaszcza $\mathrm{z}$ medycznego punktu widzenia jest on trudny. Zmiany fizjologiczne okresu klimakterium, dodatkowo, schorzenia ogólnoustrojowe dotyczace 
wieku średniego, zmiany w życiu rodzinnym, zawodowym, społeczno-ekonomicznym mają istotny wpływ na ogólną kondycję psychospołeczna i fizyczna kobiety w wieku średnim, co bezpośrednio rzutuje na poczucie jakości życia.

Wiek średni to najdłuższy okres dorosłego cyklu życia człowieka. $\mathrm{O}$ jego naturze decydują czynniki indywidualne, ale również społeczno-kulturowe. Dyskurs społeczny dotyczacy wieku średniego toczy się obecnie wokół dwóch różnych interpretacji. Pierwsza określa wiek średni jako czas kryzysu (np. rozpad małżeństwa), czas stagnacji, negatywnej oceny siebie a nawet zagrożenie depresją. Przeciwny mu jest nurt określający wiek średni jako okres rozwojowy, w którym człowiek na bazie samopoznania i samoakceptacji zmierza do harmonii ze światem.

Można założyć, iż sposób reagowania na zmiany, które zachodzą w życiu człowieka, w tym także zmiany zachodzace w organizmie, spostrzeganie procesu starzenia się wpływa na sposób postrzegania samego siebie. Wiek średni sprzyja analizie przeszłości, swoich osiagnięć zawodowych i rodzinnych, a antycypacja przyszłości prowadzi do oceny wartości i jakości swego życia.

$\mathrm{Z}$ wejściem człowieka w wiek średni wiąże się jeszcze inny aspekt, mianowicie na wiek średni przypadaja tzw. zadania rozwojowe, którym należy podołać. Pierwsze, związane ze świadomością przemijania, dotyczy przeanalizowania i oceny przeszłości. Wynika ono częściowo z pragnienia racjonalnego wykorzystania kolejnego etapu życia. Pomaga pozbyć się młodzieńczych iluzji czy też nieadekwatnych do rzeczywistości przekonań o sobie i świecie. Drugie zadanie polega na obraniu kierunku dalszych działań w życiu zarówno na niwie osobistej jak i zawodowej. To właśnie na wiek średni najcześciej przypadaja takie zmiany jak rozwód, zmiana pracy czy stanowiska (zmiany zewnętrzne) oraz przewartościowanie perspektywy społecznej, a także wartości osobistych (zmiany wewnętrzne). Z kolei trzecie zadanie rozwojowe znajduje swoje odzwierciedlenie w indywiduacji. Człowiek na tym etapie życia ustosunkowuje się wobec siebie i świata, co pozwala na zdystansowanie się do dotychczasowych doświadczeń indywidualnych oraz społecznych.

Odwołując się do różnych koncepcji rozwoju społecznego człowieka, można przywołać myśl Junga, który uznawał, że prawidłowy rozwój osobowości człowieka w wieku średnim obejmuje dwa cele: sfinalizowanie fazy indywidualizacji oraz wejście w fazę transcendencji. Pierwszy ze wskazanych celów, w odniesieniu do kobiet wieku średniego, wskazuje na umiejętności asertywności, przywiązywania większej wagi do znaczenia pracy zawodowej i problemów z nią związanych. Drugi cel określa kobietę bardziej niż dotychczas zorientowaną na zewnątrz, 
ukierunkowaną na przekazywanie swojej wiedzy, doświadczeń i koncepcji świata następnym pokoleniom.

Dla kobiety jednak wiek średni jest przede wszystkim czasem przekwitania, menopauzy. Według Światowej Organizacji Zdrowia (WHO) menopauza jest naturalnym, fizjologicznym stanem wynikajacym z wygasania czynności hormonalnej jajników. Z medycznego punktu widzenia przebiega ona trójetapowo (okres przedmenopauzalny, okołomenopauzalny, pomenopauzalny) i w naszej strefie klimatycznej pojawia się między 45 a 55 rokiem życia kobiety. Objawy, które towarzyszą temu okresowi są bardzo indywidualne (tzw. zespół klimakteryjny) ${ }^{1}$. U ponad 89\% kobiet pojawiaja się objawy neurowegetatywne (jak na przykład uderzenia krwi do głowy, bóle i zawroty głowy, nadmierne pocenie się) i psychiczne (najczęściej występuje chwiejność emocjonalna, drażliwość, osłabienie pamięci a nawet depresja). Na przestrzeni ostatnich 100 lat przeciętny okres życia kobiety w krajach cywilizowanych wydłużył się prawie o 30 lat, ale okres występowania menopauzy przesuną się jedynie o 1-1,5 roku, co oznacza, że 1/3 życia kobiety, w tym kilkanaście lat aktywnej pracy zawodowej, przypada na okres po przekwitaniu.

Jak wynika z obserwacji i doświadczeń medycznych, w związku $\mathrm{z}$ przemianami hormonalnymi kobiety najbardziej cierpia w latach poprzedzających wiek średni, nawet 8-10 lat przed wejściem w okres menopauzy. Spadek energii, zmienność nastroju, brak libido to tylko niektóre dolegliwości, o których mówia kobiety. Wchodzenie w okres menopauzy oznacza, że organizm kobiety doświadcza wielu istotnych zmian. Przemianie podlega nie tylko fizyczność kobiety, ale i jej psychika. Poczucie bezpowrotnej utraty części kobiecości wzmaga fakt, iż w naszym społeczeństwie nadal utrzymuje sie przekonanie, że kobieta $\mathrm{w}$ średnim wieku traci wartość w aspekcie atrakcyjności fizycznej i społeczno-zawodowej. Dodatkowo, kobiete dopada syndrom pustego gniazda, z którym nie zawsze jest w stanie sama się uporać. Należy jednak zwrócić uwage, że we współczesnych polskich rodzinach obserwuje się nowy trend: pełne gniazdo. $\mathrm{Z}$ wielu przyczyn młodzi ludzie zostaja w domach rodzinnych, a na plan pierwszy wysuwaja się trudności finansowe. Wśród pozostających „przy rodzicach” są i tacy, którzy jeszcze się kształca, opóźniają zawarcie związku małżeńskiego lub też

\footnotetext{
${ }^{1}$ Choć w mowie potocznej pojęcie klimakterium i menopauza używa się zamiennie, maja one różne znaczenia. Menopauza - to ostatnia w życiu kobiety miesiączka spowodowana ustaniem pracy jajników, po której przez okres 12 miesięcy nie pojawi się następna. Klimakterium, zwane również okresem przekwitania, to okres kilku lat przed i kilka lat po menopauzie. Obejmuje wszystkie zmiany w fizjologii i samopoczuciu kobiety. Samo w sobie nie jest jednostka chorobowa, ale intensywność objawów może wpłynać w tak istotny sposób na jakość życia kobiety, że konieczne staje się odpowiednie leczenie.
} 
po prostu zdążyli się rozwieść. Jednym z bardziej dokuczliwych problemów związanych z przechodzeniem menopauzy jest chwiejność emocjonalna, która stanowi źródło konfliktów z najbliższymi osobami oraz otoczeniem społecznym. Najbardziej jednak bolesny dla kobiety okazuje się fakt uświadamiania przez najbliższych jej stanów emocjonalnych. Warto dodać, że w literaturze przedmiotu panuje pogląd, iż kobiety o wyższym statusie materialnym i społecznym oraz te, u których relatywnie wcześnie wystąpiły objawy menopauzy, skupiaja się na pozytywnych aspektach zmian wynikajacych z doświadczania przekwitania. Stan ten traktuja jako chwilową niedogodność, a przede wszystkim nie odczuwaja utraty kobiecości. Wśród kobiet sa i takie, które uważaja, że wkroczenie w wiek średni stanowi najbardziej harmonijny okres życia. Zazwyczaj dorosłe już dzieci, ustabilizowana sytuacja zawodowa daja im możliwość dysponowania większą ilością czasu dla siebie, mogą rozwijać zainteresowania czy też realizować marzenia.

Jednak, aż 30\% ogólnej populacji kobiet wchodząc w okres menopauzy izoluje się społecznie, odczuwa bezradność i dyskomfort w związku ze zmianami jakie tocza się w sferze psychofizycznej. Takie zmiany fizyczne jak szybkie męczenie się, trudności z koncentracja czy pamięcia nie sa tak dotkliwe jak zmiany dokonujące się w obrębie życia emocjonalnego i psychicznego kobiety. Zazwyczaj pierwsze objawy menopauzy utożsamiane sa z końcem kobiecości. Negatywne emocje, spadek samooceny, zamykanie się w sobie to najczęściej pojawiajace się reakcje na pierwsze oznaki wchodzenia w okres klimakterium. W kontekście społecznego funkcjonowania kobiety objawy fizyczne sa bardzo dotkliwe i stresogenne. Chociażby tzw. uderzenia goraca, nad którymi trudno zapanować, demaskuja kobietę, zmniejszaja jej poczucie pewności w relacjach z innymi, powoduja spadek poczucia bezpieczeństwa oraz poczucia wartości. W opinii kobiet straty te przekładaja się na mniejszą z ich strony efektywność i chęć działania.

Już w 1926 r. Jan Christian Smuts (południowoafrykański filozof), tworzac podstawy modelu medycyny holistycznej, zauważył, że przy ocenie kondycji zdrowotnej człowieka i jego poczucia jakości życia nie można pomijać kontekstu społeczno-kulturowego oraz rodzinnego. Kulturowo usankcjonowane oczekiwania społeczne wobec pełnienia określonych ról społecznych (np. kobiety/mężczyzny, matki/ojca, żony/męża) nie zawsze sa spójne $\mathrm{z}$ potrzebami jednostki. Narzucone kulturowo i społecznie wymagania stają się źródłem cierpień, stoją w opozycji do zadowolenia z życia, a przeciwstawienie się w realizacji oczekiwań społecznych może okazać się bardziej dotkliwe.

Powyższym refleksjom towarzyszyła potrzeba poznania problemu od strony empirycznej. Bodźcem do badań było przekonanie, że wiedza 
na temat społecznego funkcjonowania kobiety wchodzacej w okres menopauzy wciąż nie jest wystarczająca, a panujące w społeczeństwie stereotypy, błędne przekonania czy też po prostu uogólnienia nie zawsze zgodne sa z rzeczywistością.

Celem badań była ocena funkcjonowania psychospołecznego kobiety w okresie menopauzy oraz poznanie wpływu relacji społecznych kobiety na jakość życia. Przyjęto założenie, że holistyczne podejście do wieku średniego kobiety może przyczynić się do pełniejszego obrazu podjętego problemu.

Badania przeprowadzone zostały w grudniu 2012 r. wśród mieszkanek Szczecina. Posłużono się metodą sondażu diagnostycznego z wykorzystaniem kwestionariusza ankiety. W konstruowaniu narzędzia badawczego uwzględniono następujace aspekty życia człowieka, które uznano za główne predykatory jakości życia kobiet w wieku średnim: czynniki socjodemograficzne, ogólny stan zdrowia, poziom wiedzy na temat menopauzy, poziom samooceny, relacje społeczne w środowisku pracy, relacje z partnerem, życie towarzyskie, bilans życiowy.

Średni wiek ankietowanych kobiet wynosił 54 lata, średni wiek wejścia w menopauze 49 lat. Tylko co czwarta respondentka $(24,2 \%)$ z pełnym przekonaniem stosowała zastępczą terapię hormonalną (średnio od 4 lat). Zdecydowana większość badanych w chwili badania $(75,8 \%)$ nie stosowała zastępczej terapii hormonalnej (tabela 3). Najczęstszym powodem nie stosowania terapii zastępczej były negatywne doświadczenia zdrowotne spowodowane terapia (gorsze samopoczucie, tycie, obrzęki) lub przekonanie, że organizm dobrze sobie radzi ze zmianami. Średnia waga kobiet przed menopauza wynosiła $62,5 \mathrm{~kg}$, w trakcie menopauzy $65 \mathrm{~kg}$, w chwili badania $66,2 \mathrm{~kg}$. Tendencja wzrostu wagi ciała dotyczyła kobiet zarówno poddających się zastępczej terapii hormonalnej jak i tych, które jej nie stosowały.

Najwięcej ankietowanych stanowiły kobiety ze średnim wykształceniem $(39,4 \%)$ oraz zawodowym $(34,8 \%)$. Zaledwie $13,6 \%$ badanych legitymowało się wykształceniem wyższym. Większość respondentek pozostawało w związku małżeńskim (63,6\% mężatek), 12,1\% kobiet było rozwiedzionych, najmniej liczną grupe stanowiły kobiety pozostające w związku nieformalnym oraz wdowy. Średnia dzietność kobiet to dwoje dzieci, w przeważającej większości dzieci nie zamieszkiwały $\mathrm{w}$ domu rodzinnym.

$\mathrm{Za}$ istotna $\mathrm{w}$ badaniu jakości życia kobiet $\mathrm{w}$ okresie menopauzy uznano kwestie zdrowia, pytano zatem o operacje ginekologiczne. 86,4\% respondentek nie przechodziła żadnej operacji ginekologicznej, $9,1 \%$ odpowiedziało twierdząco (usunięcie macicy, wycięcie polipa, usunięcie nadżerki), a $4,5 \%$ oczekuje na operację. 
Na wykresie 1 uszeregowano najczęstsze objawy menopauzy (w narzędziu badawczym istniała możliwość zaznaczenia wszystkich dolegliwości, które dotyczyły badanych kobiet). Warto dodać, iż nie znaleziono związu między stosowaniem zastępczej terapii hormonalnej a wskazaniami mniejszej ilości objawów menopauzy. Zarówno kobiety z wyższym wykształceniem, jak i zawodowym podkreślały niemal wszystkie objawy menopauzy. Także kobiety, które obecnie stosuja zastępcza terapię hormonalną oraz te, które jej nie stosują zaznaczyły podobną ilość objawów.

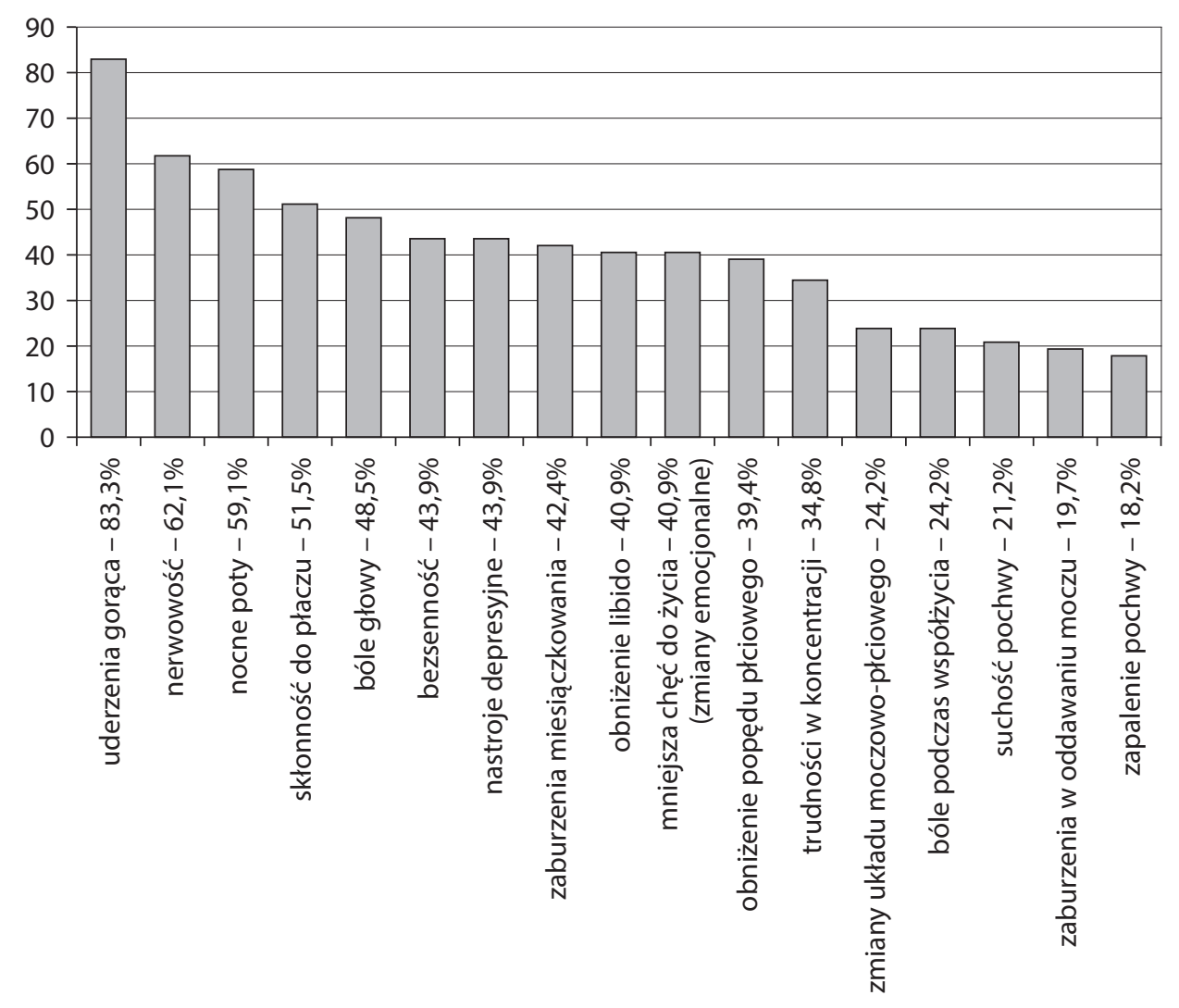

Wykres 1. Objawy menopauzy

Źródło: opracowanie własne

Wykres 2 ukazuje zróżnicowanie zawodowe badanych kobiet. Bez względu na wykształcenie i wykonywany zawód badane kobiety maja potrzebe wiedzy na temat menopauzy i związanym $\mathrm{z}$ nią problemem osteoporozy (wykres 4). Aż $45 \%$ kobiet odpowiedziało, że „osteoporoza to ważny problem kobiety związany z menopauza, dlatego staram się wiedzieć na ten temat jak najwięcej”. Jedynie $9 \%$ uznało, że ten temat ich nie dotyczy. 


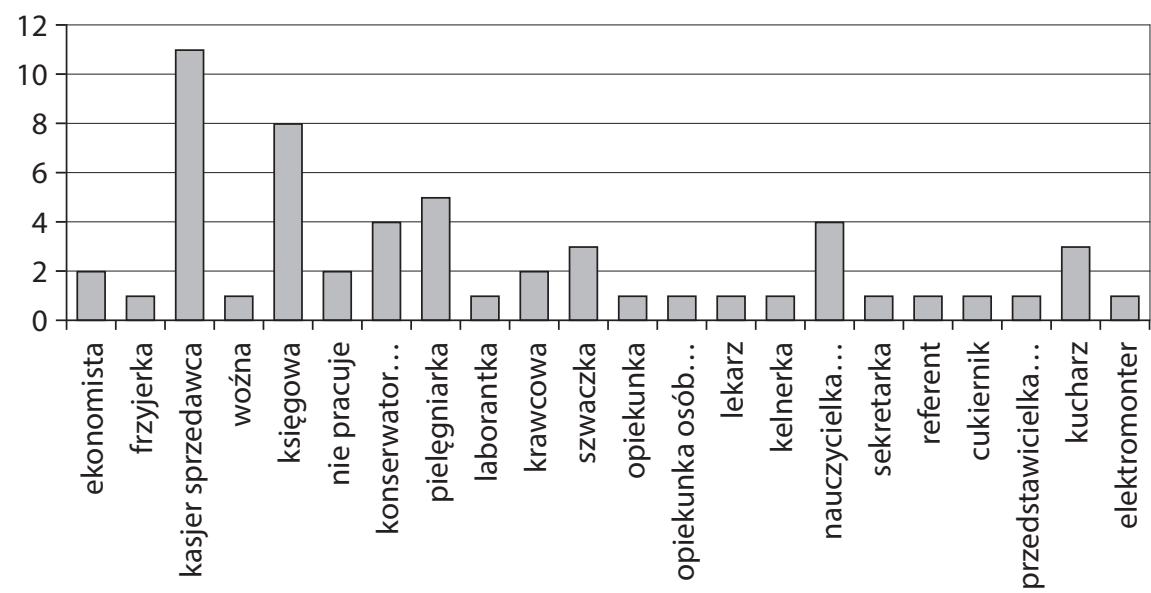

Wykres 2. Wykonywany zawód

Źródło: opracowanie własne

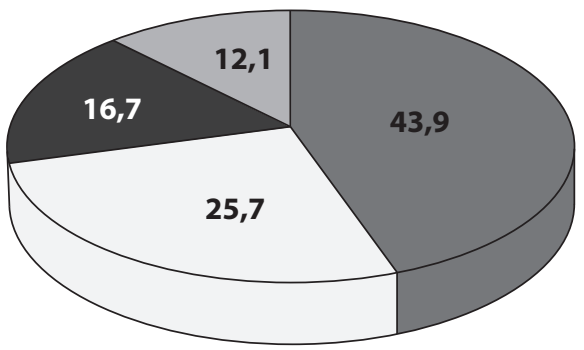

Nie, ponieważ uważam, że mój organizm dobrze daje sobie radę z tą zmianą - 43,9\%

Tak, jestem przekonana o ich skuteczności $-25,7 \%$

Nie, ponieważ kiedy zaczęłam je stosować czułam się gorzej - 16,7\%

Tak, ale nie jestem przekonana o ich skuteczności - 12,1\%

Wykres 3. Wspomaganie się lekami hormonalnymi w związku z wejściem w okres menopauzy

Źródło: opracowanie własne

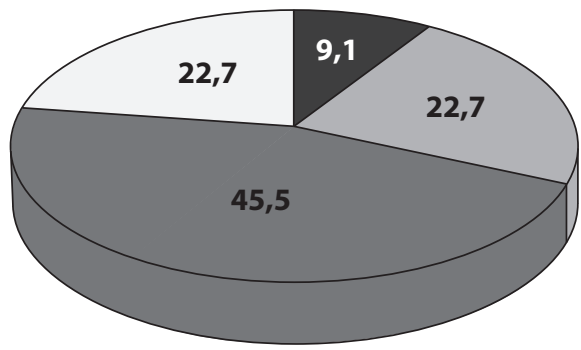

Myślę, że ten temat mnie nie dotyczy

Uważam, że to ważny problem kobiety związany z menopauzą, ale nie przejmuję się tym za bardzo

$\square$ Uważam, że to ważny problem kobiety związany z menopauzą, dlatego staram się wiedzieć na ten temat jak najwięcej

$\square$ Wiem bardzo dużo na ten temat i staram się dostosowywać swój tryb zycia oraz żywienia do tego co radzą lekarze

Wykres 4. Wiedza na temat osteoporozy

Źródło: opracowanie własne 
Jedynie, co czwarta, respondentka poddała się zastępczej terapii hormonalnej, będąc przekonana o jej skuteczności (wykres 3). Prawie połowa badanych kobiet wierzy w moc swego organizmu. Najmniej liczna grupe stanowia kobiety, które wspomagaja sie lekami hormonalnymi, ale bez przekonania o ich skuteczności działania. W większości przypadków sa to kobiety, które od niedawna (średnio od 4 lat) zdecydowały się na zastosowanie terapii hormonalnej.

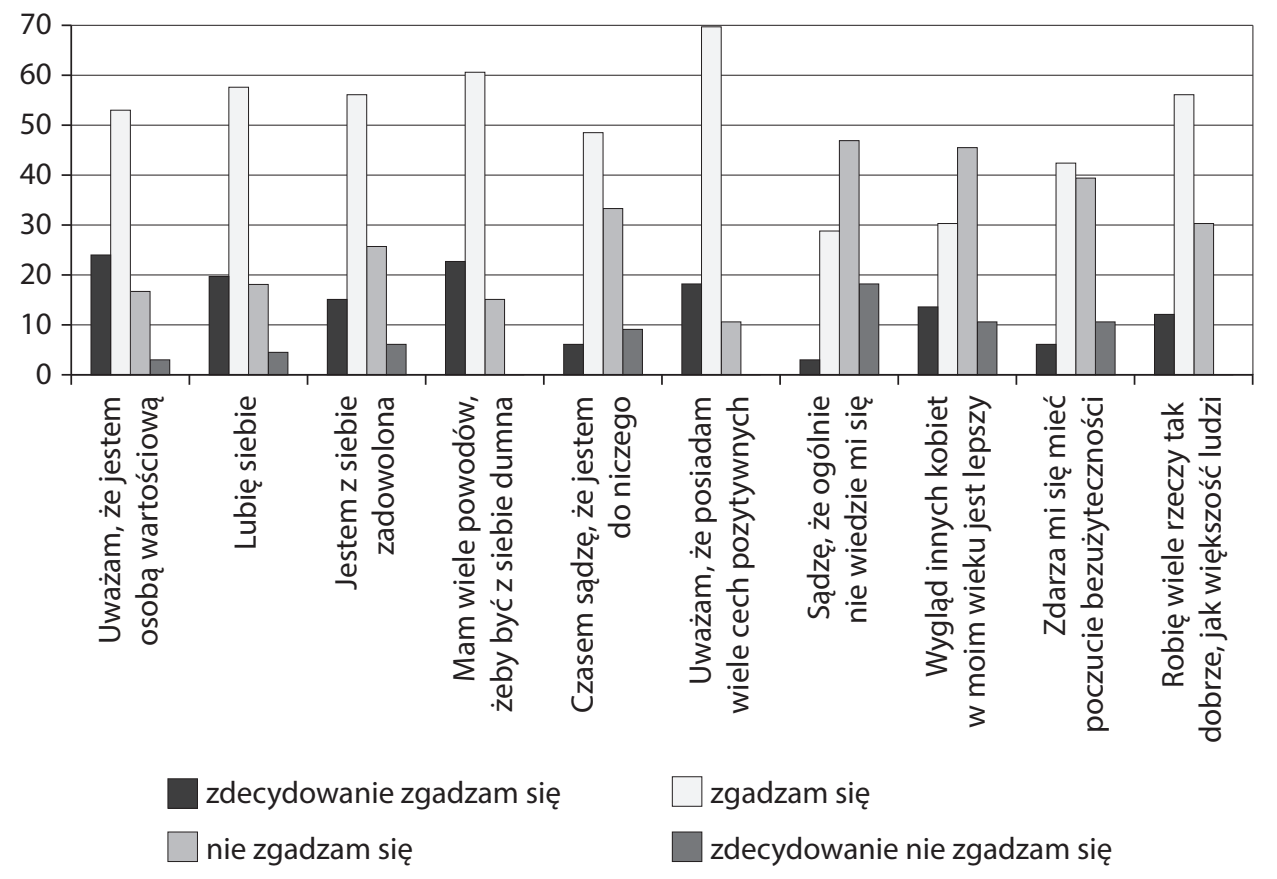

Wykres 5. Samoocena respondentek

Źródło: opracowanie własne

Samoocena to dokonywane przez człowieka oszacowanie wartości samego siebie (Aronson E. i in.1997). Kształtowanie obrazu i oceny własnej osoby zachodzi pod wpływem osobistych doświadczeń jednostki, jak i w oparciu o sądy i opinie innych osób. Koncepcja interakcjonizmu symbolicznego zakłada nieustanne uwikłanie człowieka $\mathrm{w}$ interakcje z własnym Ja lub z innymi ludźmi. Podczas interakcji z innymi dochodzi do otrzymywania społecznej informacji zwrotnej dotyczącej Ja, która kształtuje samoocenę człowieka. Innym ważnym źródłem samooceny jednostki sa porównania społeczne. To, w jaki sposób człowiek ocenia siebie determinuje jego zachowanie, funkcjonowanie i samopoczucie. Można mówić o trzech istotnych determinantach wpływajacych na poziom samooceny. Po pierwsze, istotne jest to, jak jednostka postrzega sama 
siebie w aspekcie atrakcyjności fizycznej, interpersonalnej i zawodowej. Po drugie, w jakim stopniu nabyła umiejętność wybaczania sobie i innym, zdystansowała się do zdarzeń i faktów, których nie można wymazać z pamięci. Po trzecie, jakie wymagania stawia sobie jednostka, jak bardzo angażuje się w realizację celów, rozwija pasje życiowe oraz potrafi dzielić swój czas na rzecz innych - partnera, dzieci, rodziców, wnuków.

Badania wykazały, że respondentki posiadaja wysoki poziom samooceny mimo, że częściej występowały odpowiedzi „zgadzam się” niż „zdecydowanie zgadzam sie” (wykres 5). Respondentki w stopniu wysokim zgodziły się z opisami pozytywnymi. O zmiennych nastojach moga świadczyć odpowiedzi dotyczące poczucia „bycia do niczego” oraz „poczucia bezużyteczności” - z tymi odpowiedziami respondentki zgodziły się w stopniu wysokim. Uznanie, że posiada się wiele pozytywnych cech było tym wskaźnikiem samooceny kobiet, z którym badane zgadzały się najczęściej. Podobnie jest ze wskaźnikiem: „posiadam powody by być $\mathrm{z}$ siebie dumna”. Nie znaleziono istotnych różnic w samoocenie kobiet $\mathrm{z}$ wykształceniem wyższym w stosunku do samooceny kobiet z wykształceniem zawodowym.

Kolejnym badawczym aspektem oceny jakości życia kobiet w wieku średnim było środowisko pracy. Poproszono respondentki o wybranie tej odpowiedzi, która opisuje atmosfere w miejscu ich pracy (wykres 6). Środowisko pracy zostało pozytywnie ocenione przez respondentki. Ponad połowa badanych $(56,1 \%)$ uznała stosunki panujace w pracy za przyjacielskie i bezpośrednie. Jedynie 4,5\% badanych kobiet wypowiedziało się negatywnie.

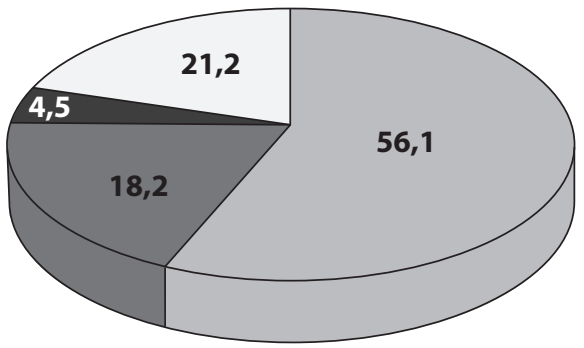
stosunki panujące w pracy są przyjazne i bezpośrednie

moi współpracownicy są mi obojętni

nikomu nie życzę takich układów międzyludzkich jakie panują w pracy

brak odpowiedzi

Wykres 6. Atmosfera w miejscu pracy

Źródło: opracowanie własne

Częścią badania objęto także kwestię relacji partnerskich/małżeńskich. Głównym powodem kryzysu więzi małżeńskich w rodzinach kobiet $\mathrm{w}$ wieku średnim jest mniejsze zainteresowanie życiem płciowym oraz poczucie emocjonalnej separacji. Otwartość na potrzeby partnera, 
umiejętność określenia wzajemnych oczekiwań warunkuja bliskość i poczucie szczęścia w związku. Respondentkom zadano pytanie o to, co jest dla nich najważniejsze w partnerze (wykres 7 ). W odpowiedziach najczęściej pojawiało się poczucie bezpieczeństwa i przekonanie, że jest się nadal kochana. Wszystkie wymienione przez respondentki oczekiwania wobec partnera miały wydźwięk emocjonalnego przywiązania i partnerstwa. W tak szerokim spektrum oczekiwań, które ukazały badania aspekt finansowy (,pieniądze”) znalazł uznanie w oczekiwaniach wobec partnera w znikomym stopniu.



Wykres 7. Oczekiwania wobec partnera

Źródło: opracowanie własne

Również analiza wyników badań dotyczących relacji z partnerem badanych kobiet jest satysfakcjonująca (wykres 8). Ujawniło się poczucie bliskości, potrzeba kontaktów emocjonalnych, poczucie bezpieczeństwa. Czynniki te w istotny sposób wpłynęły na psychiczna kondycję badanych kobiet, zwłaszcza w momencie wchodzenia w okres menopauzy (jedna z respondentek podzieliła się uwaga, iż na wieść o jej fizjologicznej zmianie mąż z pełną serdecznością powiedział, że to znaczy, że czas na wnuki).

Życie towarzyskie, potrzeba bliskości z innymi, posiadanie więzi społecznych, które pozwalają na utrzymywanie pozytywnych relacji z innymi stanowi jedna $\mathrm{z}$ fundamentalnych potrzeb człowieka. Rola otoczenia społecznego ('́rodowisko znajomych, przyjaciół) jest istotna na każdym 
etapie rozwoju człowieka, a szczególnie w momentach najtrudniejszych dla jednostki. W okresie wieku średniego grupy towarzyskie spełniaja co najmniej trzy cele: sa źródłem wsparcia (zwłaszcza w sferze psychologicznej: porada, wysłuchanie, możliwość podzielenia się smutkiem i radościa), stanowią źródło społeczno-ekonomicznego sukcesu (grupa przyjaciół czasami może służyć jako instrument osiagnięć zawodowych, społecznych, ekonomicznych), dają możliwość utrzymywania pozytywnego wizerunku siebie (dodawanie odwagi, pochwała, podzielanie sadów i opinii, przyjaciele są źródłem konstruktywnej krytyki).

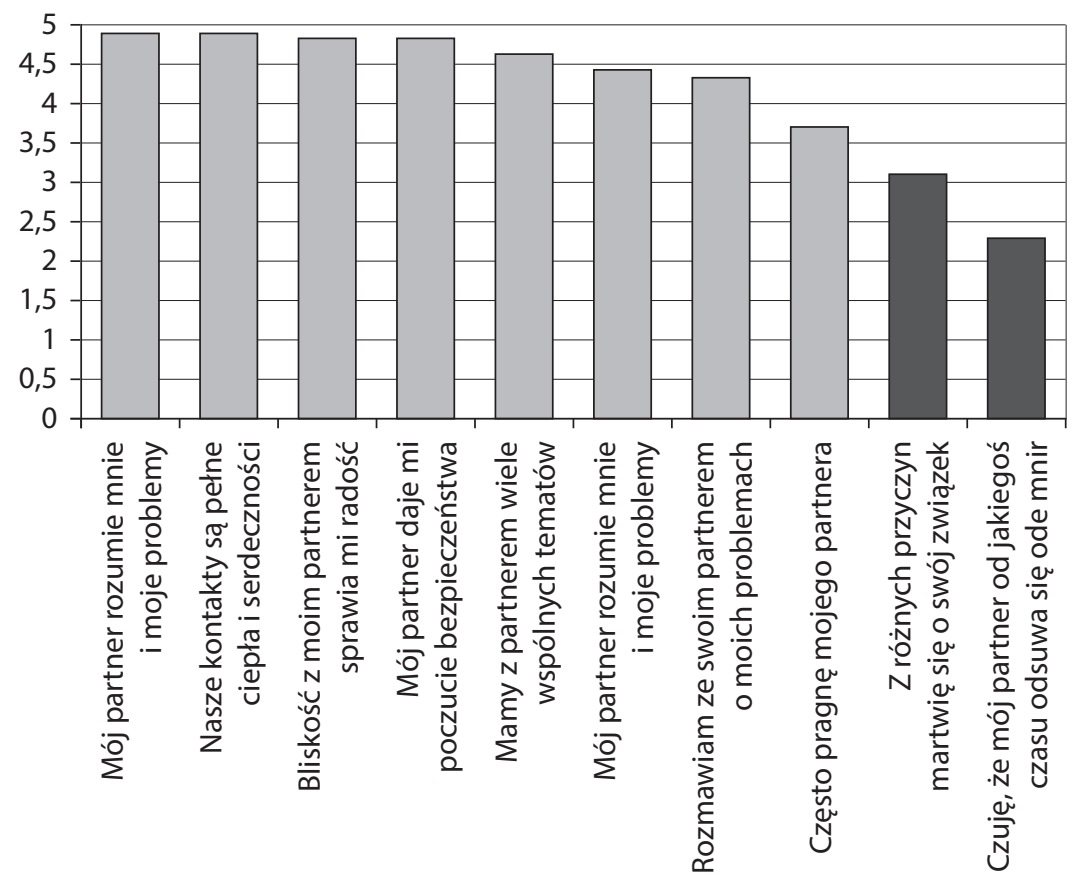

Wykres 8. Relacje z partnerem

Źródło: opracowanie własne

Badane kobiety określiły swoje życie towarzyskie jako udane $(42,9 \%)$ i bardzo udane $(17,5 \%)$, co pozwala stwierdzić, że więzi towarzysko-przyjacielskie odgrywają istotną rolę w życiu kobiet w wieku średnim, sa ważnym składnikiem ich życia (wykres 9). Ponad połowa badanych $(51,6 \%)$ posiada potrzebę spotkań, rozmów, otrzymywania porad od znajomych. Najmniej liczna grupe stanowiły kobiety, które określiły się typem samotnika, który nie przepada za życiem towarzyskim $(3,1 \%)$. Istotne jest to, że co 3 respondentka nie wyobraża sobie swojego obecnego życia bez znajomych i przyjaciół $(32,8 \%)$. 


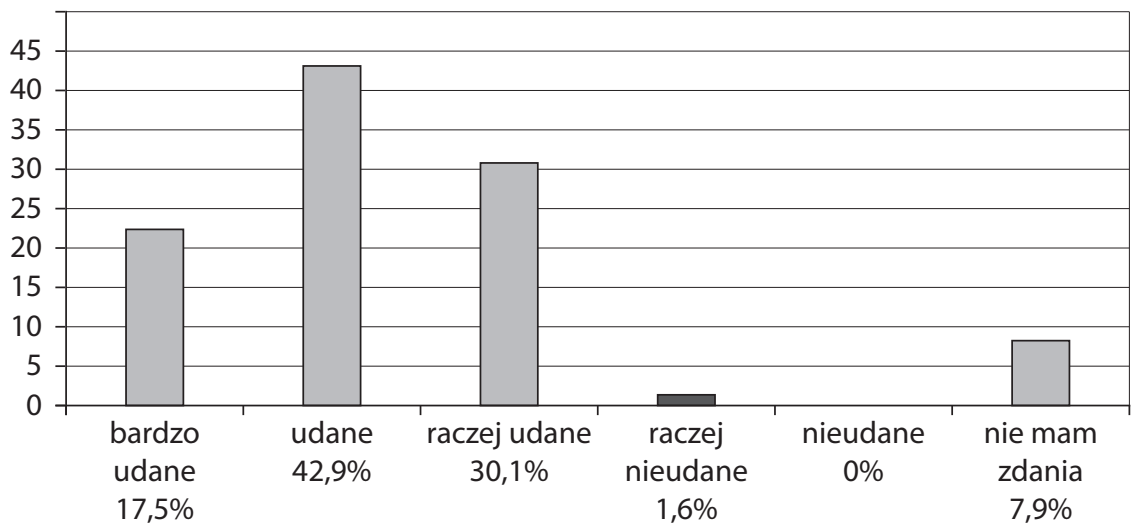

Wykres 9. Ocena życia towarzyskiego

Źródło: opracowanie własne

Bilans życiowy to jedna z trudności, na jaką napotyka kobieta będąca w wieku średnim. To również ważny składnik oceny. Poczuciu bycia na półmetku sprzyja rozpamiętywanie porażek i błędów z przeszłości, co często doprowadza do zbytniej koncentracji na sobie, stagnacji, a także braku troski o najbliższych. Tęsknota za młodzieńczym wyglądem, świadomość przemijania moga zrodzić frustracje. Jeśli bilans życiowy, ocena dotychczasowego życia sa pozytywne, kobieta $\mathrm{z}$ optymizmem patrzy w przyszłość.

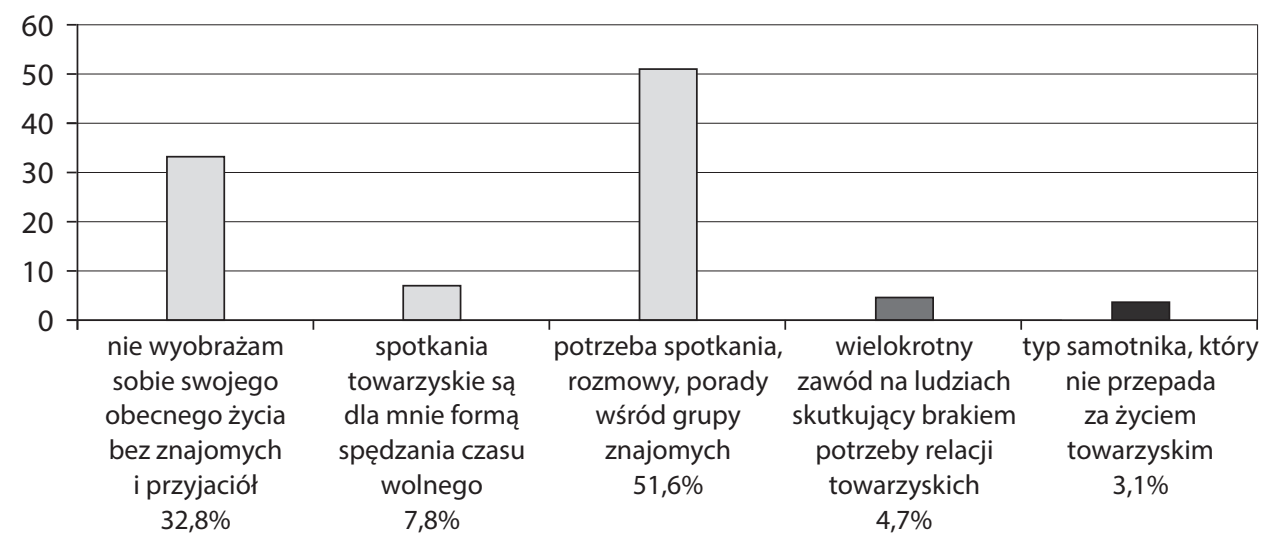

Wykres 10. Własny stosunek do życia towarzyskiego

Źródło: opracowanie własne

Badania nie ukazały kobiety w wieku średnim jako osoby umartwiającej się przemijaniem, smutnej, wspomagającej się suplementami, 
rozpamiętującej przeszłość i walczącej z nadwagą. Opinie szczecinianek, które wzięły udział w badaniach dały podstawy do wysunięcia ostrożnego wniosku, że współczesna kobieta w wieku średnim jest pewna siebie i swoich potrzeb. Badania nie potwierdziły dotychczasowego przekonania o zbawiennej i wspomagającej roli zastępczej terapii hormonalnej. Natomiast znajduje przełożenie rola relacji partnerskich/ małżeńskich w ocenie jakości życia kobiety. Wsparcie emocjonalne w mężu, rodzinie, grupie towarzyskiej i zadowolenie z dzieci oraz wnucząt daja kobiecie $\mathrm{w}$ wieku średnim największe zadowolenie $\mathrm{z}$ życia. Mniejsze znaczenie przy ocenie jakości życia miała praca zawodowa respondentek, w której niekoniecznie poszukuja źródła zadowolenia, aczkolwiek środowisko pracy nie może być pomijanie przy ocenie jakości życia każdego człowieka.

Należy dodać, że ocena jakości życia kobiety w wieku średnim ma sens, jeśli uwzględni się w niej dwa paradygmaty, które stanowią holistyczne i podmiotowe podejście do kobiety. Niezmiernie ważne jest, by wykorzystać ocene jakości życia nie tylko na potrzeby medycyny, choć, rzecz jasna, poznanie potrzeb pacjentki umożliwia wybranie racjonalnego i najkorzystniejszego postępowania lekarskiego. Chodzi również o to, by kobietom w wieku średnim stworzyć takie warunki społecznego funkcjonowania aby mogły one z godnością i spokojem kontynuować role społeczne oraz pełnić nowe role, a jakości swojego życia przypisywać wysoką wartość.

\section{Bibliografia}

Aronson E., Wilson T.D., Akert M. (1997), Psychologia społeczna, serce i umyst, Poznań. Bińkowska M., Pietrzak B., Dębski R. (2005), Hormonalna terapia zastępcza w grupie kobiet polskich w wieku 45-54 lat. Wiedza, opinie, zastosowanie, „Przeglad Menopauzalny", nr 2, s. 19-27.

Papuć E. (2011), Jakość życia - definicje $i$ sposoby jej ujmowania, „Current Problems of Psychiatry", Medical University of Lublin, no. 12, s. 143.

Tobiasz-Adamczyk B. (1996), Jakość życia w naukach społecznych i medycynie, „Sztuka Leczenia", nr 2, s. 33- 40.

\section{Quality of life in middle-aged women - a holistic approach}

Quality of life and health status are highly valued by the value of every human being. The sense of well-being in terms of both emotional and influenced by a variety of health factors. The idea of holistic medicine is to treat the person as a unity of body, mind and soul. The idea of holism refers to the action-oriented bio-psychosocial model of health. 
In the medical community there is a feeling of the need to take action not only diagnostic - therapeutic. Attention is also drawn to the psychosocial dimension of health-related changes at different stages of human life.

For women with a mean age of menopause is a particular change, both in terms of biological and mental. Identify the psychosocial dimension of these changes can be used to improve the aspirations of categories such as quality of life: physical functioning, social activity and vitality of the middle-aged women.

This article attempts to assess psychosocial functioning in menopausal women. It's made to analyze the influence on the assessment of climacteric symptoms and mental status, relationships with other people (partner, child, environment, social and professional), professional activity and self-esteem. It's worth to notice the ways of describing currently life achievements of women in the middle age.

Keywords: quality of life, middle age. 